\title{
Cow-calf management practices in Mexico: Reproduction and breeding
}

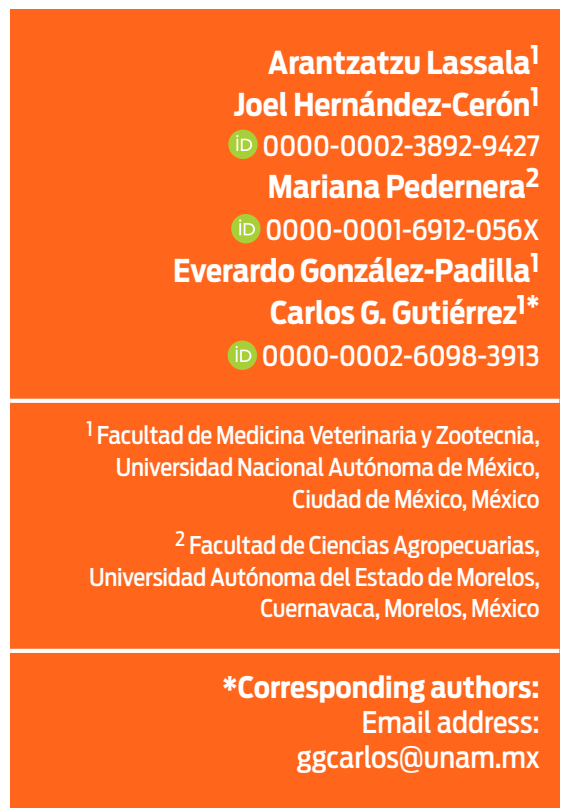

Accepted: $2019-03-12$

Published: $2020-03-31$

Additional information and declarations can be found on page 14

@ Copyright 2020 Arantzatzu Lassala et al.

open access $\boldsymbol{\gamma}$

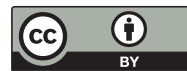

Distributed under Creative Commons CC-BY 4.0

\section{Abstract}

Beef cattle breeding has developed in extensive grazing systems in Mexi$\mathrm{co}$, concerning the livelihood of over one million families and affecting the use of natural resources. Reproductive efficiency is a major determinant of both the environmental impact of the herd, and the economic viability of the cow-calf production system. As reproductive traits have low heritability, reproductive efficiency can be largely influenced by herd management practices. Thus, a questionnaire was administered as personal interviews to 3280 producers, to investigate the prevalence of practices that could directly influence the reproductive outcome of their cattle. Results show that yearround breeding (93\%) and natural service by the bull (97.4\%) are the most common mating methods. However, only $41 \%$ of producers evaluate the breeding soundness of their bulls, and diagnostic testing for specific reproductive diseases of the sires is barely performed in $20 \%$ of the farms. The main declared reason for replacing the bull is old age (26.8\%), which is followed by to avoid inbreeding (68.4\%). Less than $10 \%$ of the operations use methods for the synchronization of the estrous cycle, and most farmers breed their heifers for the first time after 2 years of age (73\%). Diagnosis of pregnancy is performed in merely $31 \%$ of operations, with $23 \%$ of the producers declaring to discard non-pregnant cows. Energy or protein feed supplements are provided to the cattle in 63\% of the production units, whilst mineral supplements are given in $79 \%$ of the farms. Calves are typically weaned between 6 months and a year of age (85\%). Only 16\% of operations vaccinate against brucellosis and $17.5 \%$ against other reproductive

\section{Cite this as:}

Lassala A, Hernández-Cerón J, Pedernera M, González-Padilla E, Gutiérrez CG. Cow-calf management practices in Mexico: Reproduction and breeding. Veterinaria México OA. 2020;7(1). doi:10.22201/fmvz.24486760e.2020.1.839. 
diseases (IBR-DVB-VSR and Leptospirosis). The present study showcases a low frequency of adoption of basic reproductive management practices by cow-calf operations in Mexico. Advancement of these practices, as well as implementation and promotion of associated technologies, denotes an area of opportunity to improve the reproductive efficiency of the national herd.

Keywords: Cow-calf production system; Beef cattle; Dual-purpose cattle; Cattle breeding; Pregnancy diagnosis; Supplementation; Bulls 


\section{Introduction}

Reproductive efficiency is a major determinant of economic viability in cow-calf production systems. In its simplest form, reproductive outcome pertains to the ability of a cow to calve and wean a calf every year. Previous studies have determined that the calving rates in Mexico (number of females calving relative to the total number of cows exposed to the bull) are between 40 and 50\%. In a nationwide study commissioned by the Ministry of Agriculture ${ }^{2}$ the pregnancy rate of the national herd was 32\%, which implies an annual calving rate of 55\%. Thus, the biologic potential of grazing cattle and the related reproductive outcome of cow-calf systems in Mexico are currently below their possibilities.

Grazing cattle farms are extensive production systems that occupy a vast and valuable stretch of the Mexican territory, affecting the quality and preservation of ecosystems. This impact can be further determined by the environmental sustainability of the production system itself. Previous studies have shown that changes in reproductive efficiency of the herd can directly affect land and water use characteristics, as well as greenhouse emissions. In fact, researchers found that reducing the calving window, twinning, and implementing management practices such as early weaning decreased the environmental impact by $3.2 \%, 9.2 \%$ and $8.3 \%$ respectively. ${ }^{3}$

Establishing the reproductive efficiency of a herd by calving rate only is simplistic, as this parameter is also affected by numerous factors including age at first parturition, pregnancy rate, cow and bull fertility, etc. However, reproductive traits generally have a low genetic heritability, thus granting significance to management environmental factors for the successful production of weaned calves. This study aimed to investigate the frequency of management practices in cow-calf systems in Mexico that may influence the reproductive efficiency of the herd. These include breeding strategies, use of reproductive technologies, pregnancy diagnosis, criteria for first mating heifers, feed supplementation, age at weaning, diagnosis and prevention of reproductive diseases and breeding soundness examination of the bull. Data were obtained through structured interviews administered directly to the managers of more than 3000 cow-calf production units across the country.

\section{Materials and methods}

Management practices and use of technology in grazing cattle production units in Mexico were characterized by a structured questionnaire that gathered descriptive information related to farm organization, broad management of the herd, occurrence of infrastructure, feeding practices, health and well being, environmental management practices, reproductive management, handling of calves, dual-purpose systems, and a section devoted to specialized dairy production in pasture. This study deals with the reproductive management of the herd.

The questionnaire was adapted from the one used by the United States Department of Agriculture (USDA) to characterize beef-calf management practices in the United States of America, ${ }^{4}$ considering adjustments and suggestions offered by experienced academics, technicians and farmers from different regions of Mexico. 
The methods and questionnaire are described in Gonzalez-Padilla et al..$^{5}$ Briefly, the sample size was calculated with a 95\% confidence level, with a probability (p) of 50\% and an estimated error (d) of 5\%.

The calculated number of questionnaires to be administered was $3158 .{ }^{5} \mathrm{~A}$ total of 3311 questionnaires were completed, of which 31 were discarded due to answer discrepancies. Finally, only farms with beef or dual-purpose herds were included for this paper, eliminating mixed herds with both purposes and specialized dairy herds in pasture. The final database was conformed of 3280 entries (Figure 1).

\section{Statistical analyses}

Each possible option within a question was considered as a binary variable. The frequency of each management practice was analyzed by REML. The results are shown as least square means and standard error of the difference (sed). Differences are declared at $p<0.05$.

Fixed variables were considered as follows:

1 Herd size: defined as small (up to 35 cows), medium (36 to 100 cows) and large (over 100 cows).

I Region: the country was arbitrarily divided in five regions according to their similarity in agro-ecological characteristics and geographical proximity, namely: North (Baja California, Baja California Sur, Chihuahua, Coahuila, Durango, Nuevo León, Sonora and Zacatecas); Center (Aguascalientes, Estado de México, Guanajuato, Hidalgo, Puebla, Querétaro, San Luis Potosí and Tlaxcala); Pacific (Chiapas, Colima, Guerrero, Jalisco, Michoacán, Morelos, Nayarit, Oaxaca and Sinaloa); Gulf (Tabasco, Tamaulipas and Veracruz), and Peninsula (Campeche, Quintana Roo and Yucatán).

- Climate: classified as arid-semiarid, temperate, dry tropics and humid tropics, according to Garcia. ${ }^{7}$

- Poverty levels were defined following municipal categories set by the National Population Council ${ }^{8}$ as very low, low, medium, high and very high.

- Land-tenure type was declared by the producer as communal land, ejido (government owned land allocated to usufructuary farmers) or private property.

\section{Results and discussion}

Over 90\% of producers in Mexico expose their cows to bulls year-round, whilst only $6.3 \%$ use seasonal breeding. Although scarce, this latter practice is more common in the northern region of the country (Table 1). Likewise, large operations use seasonal breeding more often (10.76\%) than small (4.27\%) or medium-size farms (6.02\%) (Table 1). Even if domestic cattle can reproduce throughout the year, studies show that there is a seasonal calving pattern in cow-calf operations, which relates to an enhanced fertility in cows that overlaps the months with greater pasture availability. Indeed, a calving record assessment of a zebu herd in the wet tropics in Mexico shows that females calve preferably during the winter and spring months, despite being exposed to the bull year-round. ${ }^{9}$ Moreover, in septentrional Europe, feral cattle herds 

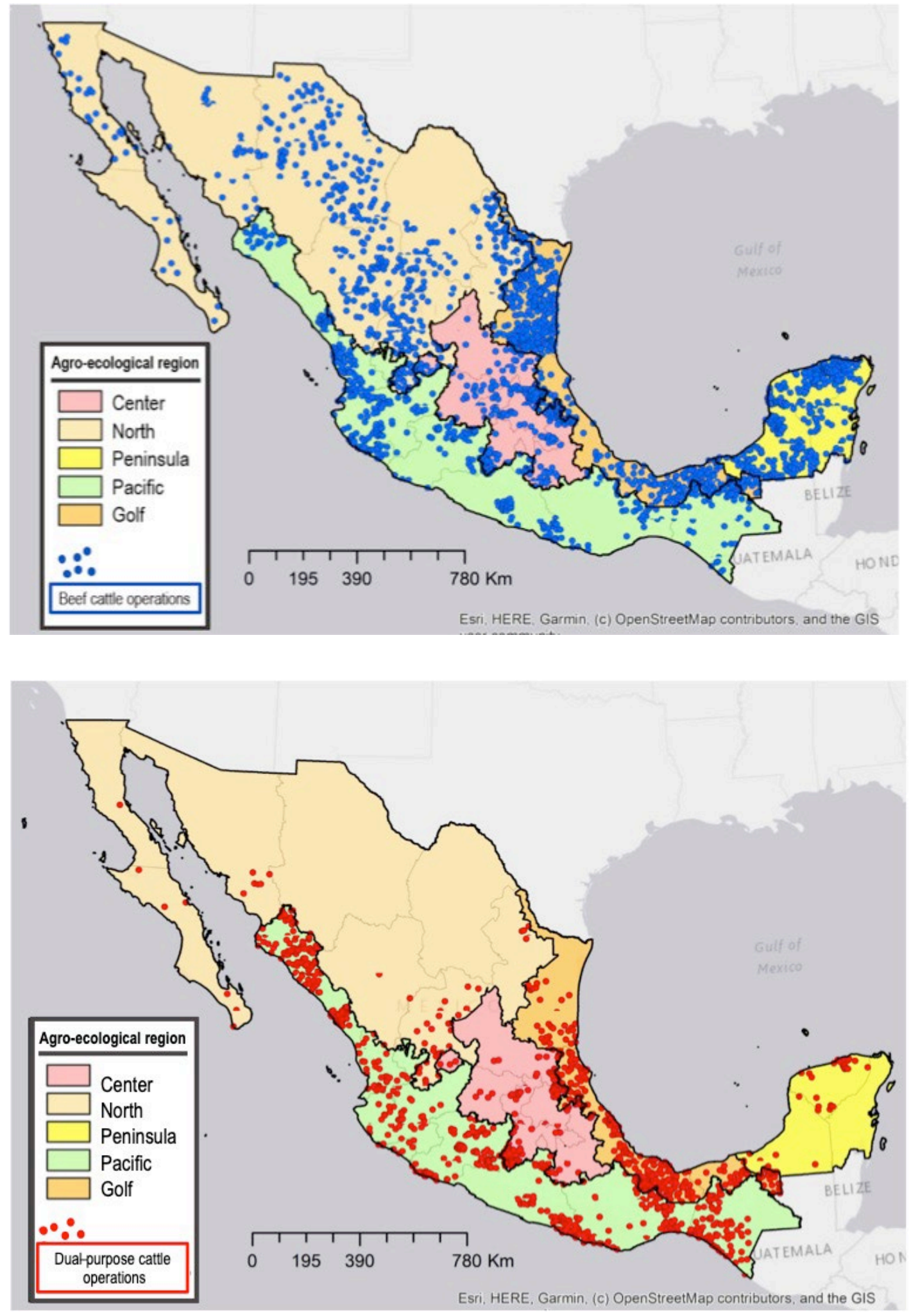

Figure 1. Distribution of surveyed beef and dual-purpose cattle operations, according to established agro-ecological regions. 
Table 1. Percentage of cow-calf operations* that execute either year-round, seasonal or split-season breeding strategies, considering population mean, region of the country where farms are located and herd size.

\begin{tabular}{|l|c|c|c|c|}
\hline & \multicolumn{3}{|c|}{ Annual breeding strategy } & sed \\
\hline & Year-round & Seasonal & Split-season & \\
\hline Population mean & 93.10 & 6.31 & 0.49 & 0.54 \\
\hline Region & & & & 1.21 \\
\hline North & 83.30 & 15.60 & 0.88 & \\
\hline Pacific & 96.15 & 3.63 & 0.22 & \\
\hline Center & 92.43 & 6.90 & 0.67 & \\
\hline Gulf & 92.34 & 6.77 & 0.74 & \\
\hline Peninsula & 99.49 & 0.25 & 0.00 & \\
\hline Herd size & & & & 0.94 \\
\hline Small & 95.35 & 4.27 & 0.31 & \\
\hline Medium & 93.54 & 6.02 & 0.44 & \\
\hline Large & 88.03 & 10.76 & 0.91 & \\
\hline
\end{tabular}

* The sum of the proportions in a given row can differ from 100\%, since presented values correspond to minimum quadratic means and/or because more than one answer was possible.

sed: standard error of the difference.

have a defined calving season when no supplementary feed is provided. ${ }^{10}$ Therefore, considering the natural seasonality of cattle may prove advantageous for producers.

Methods to synchronize estrus are rarely used in cow-calf systems in Mexico (9.1\%), even if more frequent in large and privately-owned farms (Table 2). The questionnaire did not enquire for the specific methods of synchronization used. Nonetheless, regardless of the protocol, wide-ranging advantages of estrous synchronization programs in a cowherd include advancing mating and shortening the calving interval, as well as a more effective use of timed artificial insemination, which can overcome the shortcomings of heat detection and use of bulls. ${ }^{11,12}$

Most grazing cattle production units use natural breeding (97.4\%), and only $4.6 \%$ of the farms use artificial insemination (Al). These frequencies do not seem to be impacted by the productive purpose of the farm (beef $v s$. dual-purpose), or by the age of females (cows vs. heifers). However, use of Al is more common in large and in privately owned operations (Table 3). The limited use of Al found for cow-calf operations in Mexico is a deterrent for the advancement of the genetic makeup of the national herd, since selection pressure is lower when using natural service (bulls). Concurring with the low frequencies found for practices such as synchronization and Al, estrus detection is used in merely $20 \%$ of the production units. Again, similar frequencies were found for this management practice for beef and dual-purpose cattle, as well as for heifers and cows.

As for the criteria that producers use to determine when to mate their heifers for the first-time, the predominant factor was age (Figure 2). Interestingly, even when the customary technical recommendation is that a heifer should reach 65\% of its mature body weight before being bred, body size and weight were only used as decisive reasons in 35\% of operations (Figure 2). Moreover, it has been previous- 
Table 2. Percentage of cow-calf operations* that use estrus synchronization protocols, considering population mean, herd size and land tenure type.

\begin{tabular}{|l|c|c|}
\hline \multicolumn{2}{|c|}{ Use of synchronization protocols } \\
\hline & & sed \\
\hline Population mean & 9.11 & 0.76 \\
\hline Herd size & & 1.35 \\
\hline Small & 7.00 & \\
\hline Medium & 7.67 & \\
\hline Large & 15.33 & \\
\hline Land tenure & & 1.58 \\
\hline Ejido & 6.59 & \\
\hline Communal & 4.53 & \\
\hline Private & 12.04 & \\
\hline
\end{tabular}

* The sum of the proportions in a given row can differ from 100\%, since presented values correspond to minimum quadratic means and/or because more than one answer was possible.

sed: standard error of the difference.

Table 3. Percentage of cow-calf operations* that use different mating methods, considering population mean, herd size and land tenure type.

\begin{tabular}{|l|c|c|c|c|}
\hline & \multicolumn{3}{|c|}{ Mating method } & sed \\
\hline & $\begin{array}{c}\text { Artificial } \\
\text { insemination }\end{array}$ & $\begin{array}{c}\text { Cow taken } \\
\text { to the bull }\end{array}$ & $\begin{array}{c}\text { Natural service } \\
\text { at pasture }\end{array}$ & \\
\hline Population mean & 4.57 & 1.25 & 97.40 & 0.43 \\
\hline Herd size & & & & 0.76 \\
\hline Small & 2.36 & 1.07 & 97.03 & \\
\hline Medium & 4.25 & 1.42 & 97.93 & \\
\hline Large & 9.38 & 1.36 & 97.43 & \\
\hline Land tenure & & & & 0.88 \\
\hline Ejido & 1.87 & 1.33 & 97.78 & \\
\hline Communal & 1.92 & 0.32 & 98.40 & \\
\hline Private & 7.23 & 1.38 & 96.90 & \\
\hline
\end{tabular}

* The sum of the proportions in a given row can differ from 100\%, since presented values correspond to minimum quadratic means and/or because more than one answer was possible. sed: standard error of the difference. 


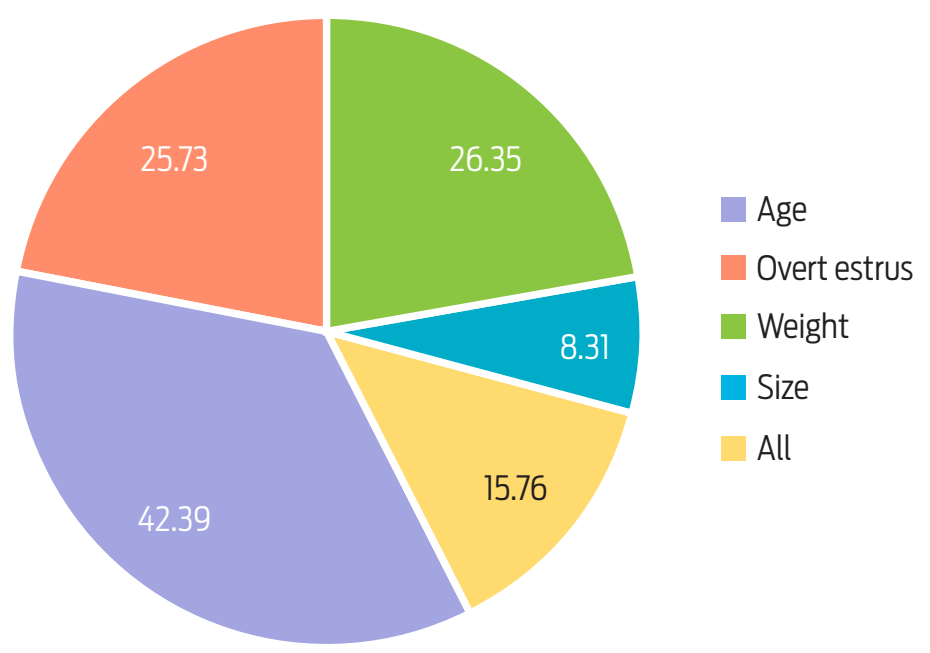

Figure 2. Criteria that producers use to determine when to mate their heifers for the first-time (values shown are percentage of the surveyed operations. sed $=1.07$ ).

ly established that heifers should be first mated between 14 and 16 months of age in intensive pasture systems, hence calving for the first time at two years of age. ${ }^{13}$ Nonetheless, most Mexican producers mate their heifers for the first time after 2 years of age (73\%), indicating that sexual maturity and puberty may be generally occurring late. Similar observations for this and other countries have been reported elsewhere. ${ }^{14}$

Forage availability and nutrient deficiencies are additional factors that may impact calving seasonality and delay puberty of heifers. ${ }^{15}$ Rainfall variability across the different agro-ecological regions of Mexico, with precipitation being more common during the summer and autumn months, and a drought period of greater or lesser extent during winter and spring, is an undisputed element impacting animal access to naturally growing grass. Thus, cattle supplementation is essential to avoid excessive body condition loss and decreased productive performance. A 63.4\% of producers in Mexico give energy or protein supplements to their cattle, mostly in spring, coinciding with the draught period (Figure 3a). In addition, this type of supplementation is more frequent in dual-purpose than in beef cattle operations $(75.5 \%$ and $57.1 \%$, respectively; sed $=1.91)$. Moreover, feed supplements are rarely given during the autumn months, when pasture is most abundant due to the rainy season (2.6\%). All year-round supplementation was reported by close to $28 \%$ of operation units (Figure 3a). In addition, this management practice is more common in temperate, arid and semiarid climates than in humid or dry tropical conditions (Figure 3b).

When supplements are provided, they are given to all the animals of the herd (68\%). Strategic supplementation based on individual physiological status is not frequently used (Table 4). However, when implemented, beef cattle farmers favor lactating animals over pregnant cows (Table 4). It is well known that strategic supplementation has better results when used to bolster body condition score at calving (ideally a BCS: 3 or above in a 1 to 5 scale should be reached). Indeed, cows calving in a better BCS have shorter postpartum intervals. ${ }^{16}$ Thus, supplementation must have enough energy dense content to meet maintenance requirements of 

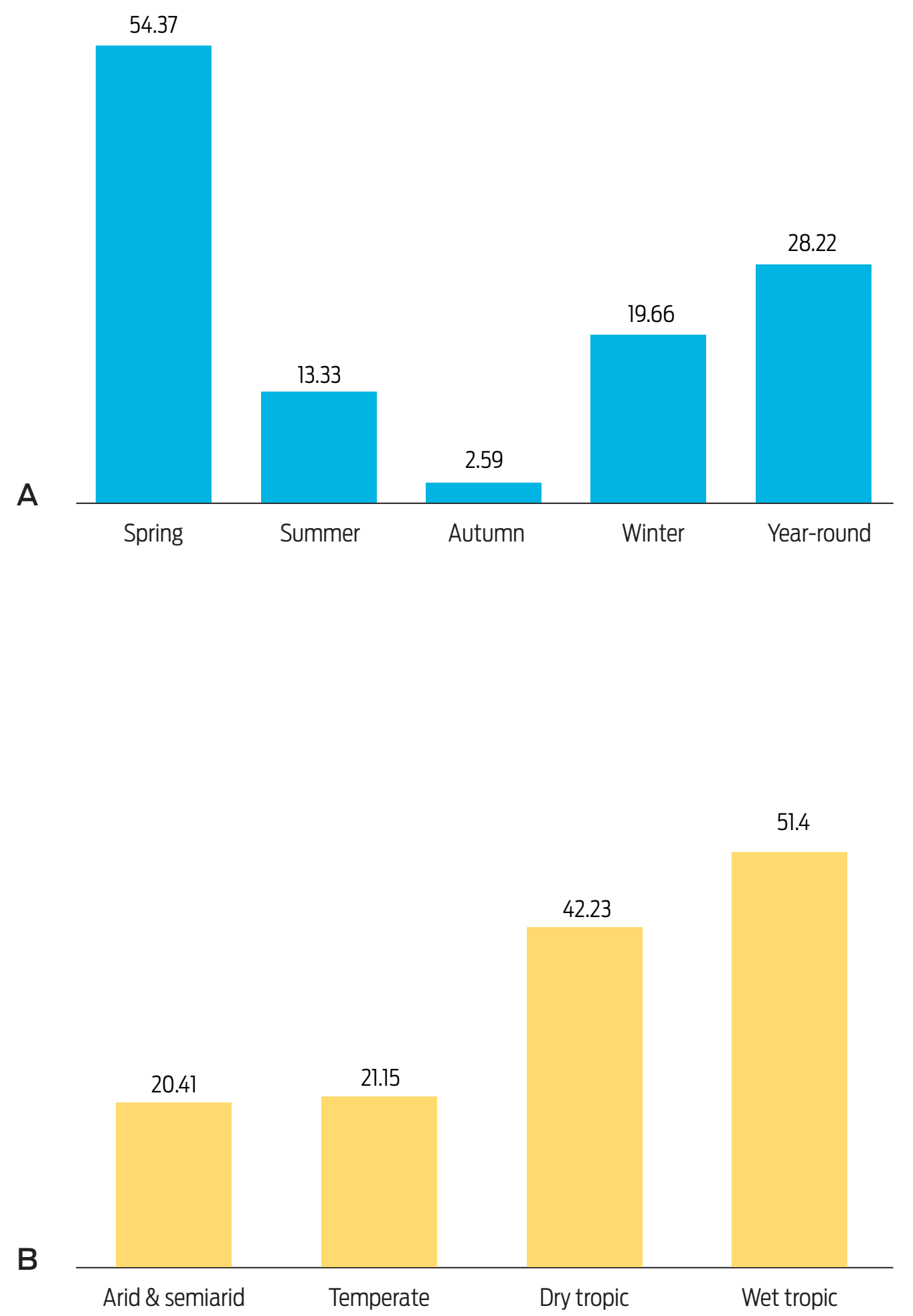

Figure 3. Use of energy or protein feed supplementation considering (A) season or (B) climate (values show percentage of the surveyed operations that provide supplements, season sed $=1.3$; climate sed $=2.85$ ). 
Table 4. Percentage of cow-calf operations* that provide energy or protein feed supplements to the cattle at different physiological stages, considering population mean and productive purpose of the operation.

\begin{tabular}{|l|c|c|c|c|c|c|c|c|}
\hline & \multicolumn{7}{|c|}{ Group of animals } & sed \\
\hline & $\begin{array}{c}\text { Suckling } \\
\text { cows }\end{array}$ & $\begin{array}{c}\text { Breeding } \\
\text { cows }\end{array}$ & $\begin{array}{c}\text { Finishing } \\
\text { cattle }\end{array}$ & $\begin{array}{c}\text { Pregnant } \\
\text { cows }\end{array}$ & $\begin{array}{c}\text { Milking } \\
\text { cows }\end{array}$ & $\begin{array}{c}\text { Backyarding } \\
\text { cattle }\end{array}$ & All & \\
\hline Population mean & $\mathbf{1 4 . 6 2}$ & $\mathbf{2 . 2 7}$ & $\mathbf{2 . 0 3}$ & 5.61 & 15.04 & $\mathbf{2 . 3 9}$ & $\mathbf{6 8 . 2 0}$ & $\mathbf{0 . 9 6}$ \\
\hline Productive purpose & & & & & & & & 1.35 \\
\hline Beef & 10.45 & 2.51 & 2.61 & 5.63 & 6.53 & 2.51 & 77.69 & \\
\hline Dual purpose & 20.70 & 1.91 & 1.17 & 5.58 & 27.46 & 2.20 & 54.33 \\
\hline
\end{tabular}

* The sum of the proportions in a given row can differ from 100\%, since presented values correspond to minimum quadratic means and/or because more than one answer was possible. sed: standard error of the difference.

Table 5. Percentage of cow-calf operations* that use the different types of nutritional supplements, considering population mean and productive purpose of the operation.

\begin{tabular}{|c|c|c|c|c|c|c|c|}
\hline & \multicolumn{6}{|c|}{ Type of supplement } & \multirow[t]{2}{*}{ sed } \\
\hline & Concentrate & $\begin{array}{l}\text { Chopped } \\
\text { forrage }\end{array}$ & Hay & Silage & $\begin{array}{c}\text { Nutritional } \\
\text { blocks }\end{array}$ & Other & \\
\hline Population mean & 37.30 & 33.30 & 28.60 & 18.70 & 17.00 & 14.60 & 1.45 \\
\hline Productive purpose & & & & & & & 2.10 \\
\hline Beef & 32.30 & 35.80 & 31.30 & 18.50 & 18.10 & 16.30 & \\
\hline Dual purpose & 44.60 & 29.60 & 24.60 & 19.10 & 15.50 & 12.10 & \\
\hline
\end{tabular}

* The sum of the proportions in a given row can differ from 100\%, since presented values correspond to minimum quadratic means and/or because more than one answer was possible. sed: standard error of the difference.

late pregnant cows and allow for an increase in BCS. ${ }^{15}$ For dual-purpose cows, supplementation is also aimed to improving milk production, hence this practice was followed thrice as often in this type of operations, when compared to beef cattle production systems (Table 4).

Concentrate is undoubtedly the most frequently used supplement by farmers (37.3\%), followed by chopped forages and hay (33.3\% and 28.6\%, respectively), whilst silage is only used by $18.7 \%$ of producers (Table 5). Preference of concentrate use over other supplement choices is probably due both to its ready availability and its high energy and protein content. Concentrate supplementation is also more frequent in dual-purpose farms than in beef cattle operations (Table 5), since it can be noticeably linked to an immediate increase in milk production.

Grass-fed cattle also require supplementation of mineral nutrients not sufficiently found in pasture. An adequate mineral mix should be specifically customized to provide the micronutrients that are deficient in the forage grown at the farm. This study did not assess the adequacy of the mineral mixtures given to the animals. However, most farmers do provide mineral preparations to their cattle 
Table 6. Percentage of cow-calf operations* that diagnose pregnancy, considering the method used and the effect of herd size.

\begin{tabular}{|l|c|c|c|c|}
\hline & \multicolumn{2}{|c|}{ Method used to presume or diagnose pregnancy } & sed \\
\hline & $\begin{array}{c}\text { Transrectal } \\
\text { palpation }\end{array}$ & $\begin{array}{c}\text { Non-return } \\
\text { to estrus }\end{array}$ & Ultrasonography & \\
\hline Population mean & 30.35 & 15.61 & 0.42 & 1.00 \\
\hline Herd size & & & & 1.74 \\
\hline Small & 23.95 & 16.07 & 0.08 & \\
\hline Medium & 28.07 & 17.43 & 0.44 & \\
\hline Large & 46.27 & 12.18 & 1.07 & \\
\hline
\end{tabular}

* The sum of the proportions in a given row can differ from 100\%, since presented values correspond to minimum quadratic means and/or because more than one answer was possible. sed: standard error of the difference.

(79.1\%), with the use of common salt persisting (15\%), and 9.2\% of the producers do not supplement minerals at all (sed $=0.93)$. Mineral addition to feed, either common salt or mixed mineral formulations, are given throughout the year (86.9 \pm 0.7) to all animals of the farm (91.5 \pm 0.52$)$.

To attain a successful cattle breeding program, a further critical management practice is pregnancy diagnosis. Surprisingly, only $30.8 \%$ of operations declared to check cows for pregnancies and 54.4\% do not diagnose pregnancy at all. Also, $15 \%$ of the producers declare the use of non-return to estrus as an indicator of gestation (Table 6). When implemented, the most common method for pregnancy diagnosis is transrectal palpation, whilst ultrasound examination is used in less than half a percentual point of the surveyed farms. Pregnancy diagnosis is more frequent in large operations (58.7\%), when compared to medium or small-sized operations ( $<45 \%$; Table 6). Methods to detect pregnancy are mostly performed by a professional (74\%; veterinarian or animal scientist), followed by the farm manager (26\%). Non-pregnant cows are normally kept in the farm and mated again, with only $23 \%$ of operations declaring absence of pregnancy as a criterion to discard animals. The most common reasons for culling cows in herds are old age (64\%), infertility problems (26.3\%), and the need to generate cash flow (13.3\%).

Pregnancy diagnosis is perhaps the most decisive technology to monitor reproductive efficiency of any breeding program. However, results of this study show that this practice is extremely disregarded in cow-calf operations in Mexico. Similarly, a survey conducted by the Department of Agriculture of the United States revealed low implementation of pregnancy diagnosis methods among farmers, which increased with size of the herd $(10.8 \%$ in herds $<50$ cows up to $58 \%$ in herds $>200$ cows; USDA APHIS). ${ }^{17}$ Interestingly, a large-scale reproductive study including more than 347 thousand cows examined by transrectal palpation in 7994 Mexican farms, showed that 32\% of the animals were pregnant and that $40 \%$ of the non-pregnant cows were cycling. ${ }^{2}$ These findings further expose an important area of opportunity to improve reproductive efficiency of the national herd by the implementation of pregnancy diagnosis in production units. 


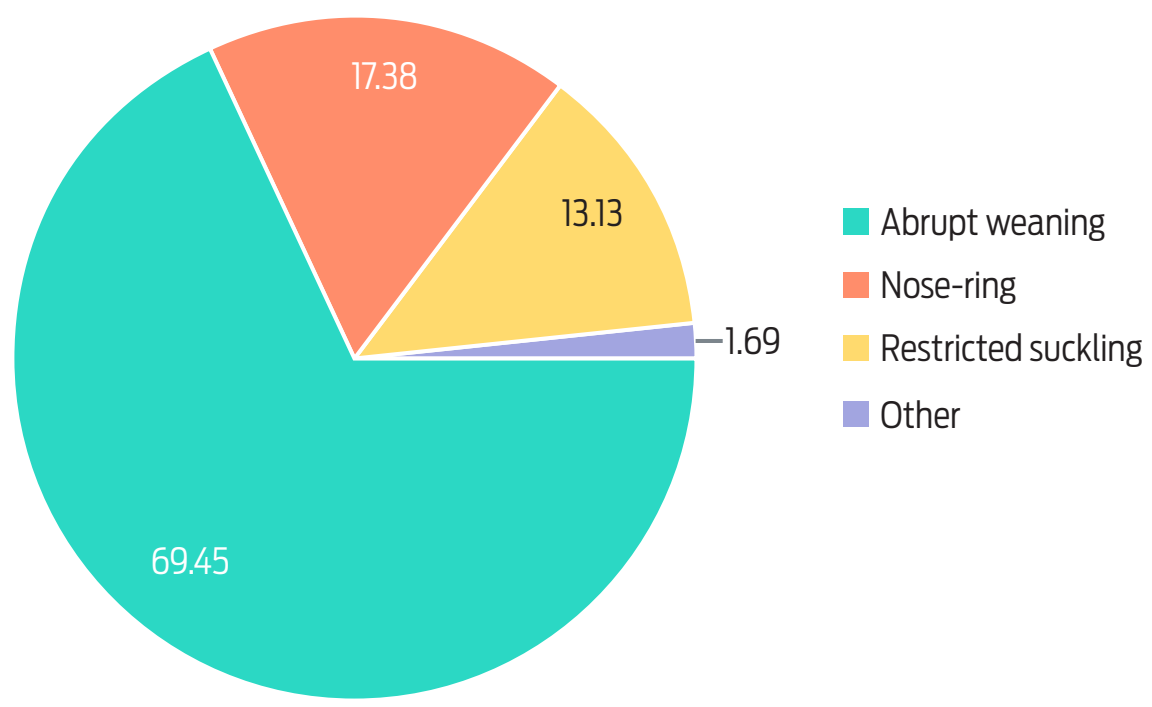

Figure 4. Calf weaning strategies used in cow-calf operations in Mexico (values show the percentage of the surveyed operations that use each method; sed $=0.9$ ).

Adequate calf weaning strategies can also improve reproductive performance of the breeder herd. This study shows that $85 \%$ of cow-calf operations in Mexico wean their calves between 6 months and one year of age. The most common approach for weaning is abrupt separation (69.4\%), while nose plates to prevent calf suckling are used by $17.4 \%$ of producers, and restricted suckling by $13.1 \%$ (Figure 4). Reports show that separation stress is reduced when nose plates, rings or flaps are used, since calves remain in the company of their dams. ${ }^{18}$ Also, the negative effects on the immune response and weight loss of the calf that generally ensue an abrupt weaning practice are minimized. ${ }^{19}$ Further, the use of nose flaps helps to maintain a higher BCS in the cows, which improves their reproductive efficiency. ${ }^{20,21}$ Restricted suckling on the other hand has been shown to advance the resumption of postpartum ovarian cyclicity and increase pregnancy rates. ${ }^{21}$ Nonetheless, this latter practice is not favored by the farmers as they believe that it is extremely stressful for young animals and requires special accommodations, as well as additional provisions to impede cows and calves from seeking to reunite during this period.

Prevention of abortive diseases is paramount for the productivity of the cowcalf production system, the main tool being vaccination. Nonetheless, prevalence of vaccination was remarkably low in the surveyed farms, even for mandatory report and compulsory immunization diseases such as brucellosis (16\%). Vaccines against other reproductive diseases, namely BVD, IBR, PI3 or leptospirosis was even lower $(<18 \%)$. Conversely, extended results of this study show that over $70 \%$ of the farmers do vaccinate their animals against potentially life-threatening diseases. ${ }^{22}$ Thus, it appears that producers neglect to appreciate welfare and economic losses that can be prompted by chronic reproductive diseases.

Breeding soundness examination of the bull plays an important role in herd reproduction. However, only $40.8 \%$ of the surveyed farms in this study have had 
Table 7. Percentage of cow-calf operations* that check breeding soundness of their bulls.

\begin{tabular}{|c|c|c|c|c|c|}
\hline & \multicolumn{4}{|c|}{ Breeding soundness examination } & sed \\
\hline & Never & At purchase & Prior to breeding & Annually & \\
\hline Population mean & 59.17 & 33.89 & 2.8 & 4.7 & 0.94 \\
\hline
\end{tabular}

sed: standard error of the difference.

their sires declared as fit at some point for entering a breeding program. Moreover, breeding soundness examination is performed mainly at the time of purchasing the bull (33.9\%), and rarely prior to breeding or at an annual basis (Table 7). Previous studies in Chihuahua ${ }^{1}$ and Costa Rica ${ }^{23}$ have shown that when examined, 15\% and $23 \%$ of the bulls respectively were not fit to reproduce. Similarly, $25 \%$ of the sires were ruled as unfit for breeding in a US report. ${ }^{24}$ Furthermore, results of this study show that specific diagnosis of venereal diseases of the bull is executed in merely $20 \%$ of farms. When performed, reproductive disease diagnoses are mainly directed to brucellosis (19.7\%), since surveillance is compulsory as part of the government campaign for disease control in livestock species. However, the presence of other venereal diseases, such as trichomoniasis, vibriosis or IBR/BVD/IBR is rarely established $(<2 \%)$. These results can be striking when considering that the preferred method for breeding the females in cow-calf systems in Mexico is by direct service, which conflicts with the very little attention that is given into ensuring the breeding soundness of bulls. Finally, the main criteria for bull replacement are to avoid inbreeding (68.4\%) and advanced age (26.8\%). Other reasons are seldom considered.

\section{Conclusions and implications}

The results of this study showcase a low adoption of reproductive management practices by cow-calf operations in Mexico. Advancement of these practices, as well as implementation and promotion of associated technologies, denotes an area of opportunity to improve the reproductive efficiency of the national herd. 


\section{Funding}

This research was supported by SAGARPA, Mexico, projectNo. 32239-1463-2-VIII-12.

\section{Acknowledgements}

Authors wish to thank all professional personnel that administered the questionnaires and captured data.

\section{Conflicts of interest}

The authors declare no conflicts of interest.

\section{Author contributions}

All authors contributed to the experimental design, manuscript drafting, discussion and preparation of the final document.

\section{References}

1. Martinez R, Lowe K, Ramirez Godinez JA. Bull reproductive evaluation under range management in the state of Chihuahua, Mexico. 1989. Available from: http://agris.fao.org/agris-search/search.do?recordID=MX8980020

2. Coordinación de Ganadería. SAGARPA. Seguimiento técnico de la situación reproductiva de los inventarios de bovinos de carne y doble propósito de los beneficiarios del componente producción pecuaria sustentable y ordenamiento ganadero y producción sustentable y ordenamiento ganadero y apícola (PROGAN). México: SAGARPA; 2012.

3. White RR, Brady M, Capper JL, McNamara JP, Johnson KA. Cow-calf reproductive, genetic, and nutritional management to improve the sustainability of whole beef production systems. J Animal Sci. 2015;93(6) 3197-211. https:// doi.org/10.2527/jas.2014-8800.

4. USDA. Beef 2007-08. Beef Cow-calf Management Practices in the United States, 2008. Available from: https://www.aphis.usda.gov/aphis/ourfocus/animalhealth/monitoring-and-surveillance/nahms/nahms_beef_ cowcalf_studies

5. González-Padilla E, Lassala A, Pedernera M, Gutierrez CG. Cow-calf management practices in Mexico: Farm organization and infrastructure. Vet México OA. 2019;6(3).

6. VSN International. Genstat for Windows. 19th ed. Hemel Hempstead: VSN International; 2017.

7. García E. Modificaciones al Sistema de clasificación climática de Koppen. $5^{a}$ ed. México: Instituto de Geografía, UNAM; 2004.

8. Índice de marginación municipal. Consejo Nacional de Población, 2013. Available from: http://www.conapo.gob.mx/es/CONAPO/Indices_de_ Marginacion_Publicaciones

9. Enríquez de la Fuente BA, Galin CS, Navarro R, Gutiérrez AC. Estimación de la época más propicia para un empadre estacional en ganado cebú bajo condiciones de trópico húmedo. Avances en Investigación Agropecuaria. 1993;2(2)101-14.

10. Towers J, Mainland I, Montgomery J, Bond J. Calving seasonality at Pool, Orkney during the first millennium $A D$ : an investigation using intra-tooth isotope ratio analysis of cattle molar enamel. Environmental Archaeology. 2017;22(1):4055. doi: 10.1080/14614103.2015.1116214. 
11. Bó GA, Baruselli PS, Mapletoft RJ. Synchronization techniques to increase the utilization of artificial insemination in beef and dairy cattle. Anim Reprod. 2013;10(3):137-42.

12. Baruselli PS, Ferreira RM, Sá Filho MF, Bó GA. Review: Using artificial insemination v. natural service in beef herds. Animal. 2018;12:S45-52. doi: 10.1017/ S175173111800054X

13. Gasser CL. Considerations on puberty in replacement beef heifers. J Anim Sci. 2013;91:1336-40.

14. Galina CS, Arthur G.H. Review of cattle reproduction in the tropics. Part 1. Puberty and age at first calving. Animal Breeding Abstracts. 1989;57:583-90.

15. D'Occhio MJ, Baruselli PS, Campanile G. Influence of nutrition, body condition, and metabolic status on reproduction in female beef cattle: A review. Theriogenology. 2019;125:277-84. doi: 10.1016/j.theriogenology.2018.11.010.

16. Morrison DG, Spitzer JC, Perkins JL. Influence of prepartum body condition score change on reproduction in multiparous beef cows calving in moderate body condition. J Anim Sci. 1999;77:1048-54.

17. Small-scale U.S. Cow-calf Operations. USDA APHIS. 2011. Available from: https://www.aphis.usda.gov/animal_health/nahms/smallscale/downloads/ Small_scale_beef.pdf.

18. Ungerfeld R, Quintans G, Hötzel M. Minimizing cows' stress when calves were early weaned using the two-step method with nose flaps. Animal. 2016;10(11):1871-6. doi:10.1017/S1751731116000793.

19. Lippolis KD, Ahola JK, Mayo CE, Fischer MC, Callan RJ. Effects of two-stage weaning with nose flap devices applied to calves on cow body condition, calf performance, and calf humoral immune response. J Animal Sci. 2016;94(2):816-23. https://doi.org/10.2527/jas.2015-9624

20. Quintans G, Banchero G, Carriquiry M, López-Mazz C, Baldi F. Effect of body condition and suckling restriction with and without presence of the calf on cow and calf performance. Anim Prod Sci. 2010:50:931-8. doi.org/10.1071/AN 10021

21. Orihuela A, Galina CS. Effects of separation of cows and calves on reproductive performance and animal welfare in tropical beef cattle. Animals (Basel). 2019;9(5):E223. doi: 10.3390/ani9050223.

22. Hernández Cerón J, Lassala A, Pedernera M, González-Padilla E, Gutiérrez GC. Manejo reproductivo del ganado bovino en sistemas de producción de carne en méxico. Reproductive management in cow-calf beef production units in mexico. Reunión Nacional de Investigación Pecuaria. Memoria, Vol. 1. 2018. p. 100-2.

23. Camacho SJ, Ramírez GS, Aguilar MP. Capacidad reproductiva de sementales en fincas ganaderas de Costa Rica. Revista UTN. 2017;80:46-50.

24. Kennedy SP, Spitzer JC, Hopkins FM, Higdon HL, Bridges WC Jr. Breeding soundness evaluations of 3,648 yearling beef bulls using the 1993 Society for Theriogenology guidelines. Theriogenology. 2002;58:947-61. 